\title{
Original article \\ Study on the flavour of soybean cultivars by sensory analysis and electronic tongue
}

\author{
Josemeyre Da Silva, ${ }^{1}{ }^{*}$ Sandra Prudencio, ${ }^{1}$ Mercedes Carrão-Panizzi, ${ }^{2}$ Camila Gregorut, ${ }^{3}$ Fernando Fonseca ${ }^{3}$ \& Luiz \\ Mattoso $^{4}$ \\ 1 Ciência e Tecnologia de Alimentos, Universidade Estadual de Londrina, Londrina, Parana, Brazil \\ 2 Centro Nacional de Pesquisa de Trigo, Empresa Brasileira de Pesquisa Agropecuária, Passo Fundo, Rio Grande do Sul, Brazil \\ 3 Escola Politécnica, Universidade Estadual de São Paulo, São Paulo, São Paulo, Brazil \\ 4 Centro Nacional de Pesquisa de Instrumentação Agropecuária, Empresa Brasiliera de Pesquisa Agropecuária, São Carlos, São Paulo, Brazil
}

(Received 25 March 2011; Accepted in revised form 25 February 2012)

Summary The scope of this study was to assess the sensory attributes of five Brazilian soybean cultivars genetically different (BRS), described as special soybean cultivars for human consumption (BRS 216, BRS 213 and BRS 267) and conventional (BRS 258 and BRS 133), by quantitative descriptive analysis (QDA), and verify the ability of the electronic tongue to discriminate the soybean cultivars according to its flavours. According to QDA, BRS 267 was characterised by increased grain size, more intense cream colour, sweet flavour, sweet and umami taste. BRS 133 showed a dark hilum colouring, cooked bean and rancid aroma, cooked bean and rancid, bitter and astringent attributes. BRS 216 presented smaller grain size, less intense cream colouring and a more rounded grain shape, while the BRS 258 showed a hard texture. BRS 213 was characterised by a neutral flavour. The electronic tongue was able to distinguish between the five soybean cultivars according to their different flavour attributes. Correlation analysis was made among chemical constituents of soybean (hexanal, linoleic and linolenic acid, isoflavones, sucrose and fructose, and glutamic acid and alanine), sensory attributes and electronic sensors. Sensory attributes had a significant correlation, in absolute value, $P \leq 0.05$, with electronic tongue $(r=0.50-0.80)$ and chemical constituents of soybean grains $(r=0.51-$ $0.98)$. Electronic tongue had a significant correlation $(r=0.50-0.94)$ with the chemical constituents. It can be used effectively to classify soybean cultivars.

Keywords Electronic tongue, flavour, principal component analysis, quantitative descriptive analysis, sensory analysis, soybean cultivars.

\section{Introduction}

Conventional soybean cultivars, classified by grain type, are used mainly to produce oil and animal feed (Liu, 1999). These cultivars display sensory properties not appreciated or undesirable flavour by consumers because of the characteristic flavour described as beany or rancid, which is caused by hexanal volatile compounds and the presence of lipoxygenase enzymes. Soybean cultivars for human consumption or food types show special chemical characteristics. These cultivars have higher protein content, sucrose, glutamic acid, alanine, lower hexanal contents and the absence of lipoxygenase enzymes that can improve the sensory qualities owing to the sweet and mild flavour (Liu, 1999).

Soybean cultivars BRS 133 and BRS 258, classified as grain type, and BRS 267, BRS 213 and BRS 216, suitable for human consumption and classified as food type, were

*Correspondent: E-mail: josibonifacio@sercomtel.com.br developed by the Brazilian Agricultural Research Corporation - Embrapa Soybean. Cultivar BRS 258 presents large seed size and yellow hilum. It originated from cultivar BR 36, which was a variety preferred by organic growers (Pípolo et al., 2005). This conventional cultivar has high yield and a great potential to be utilised for food processing (Pípolo et al., 2005). BRS 216 (Carrão-Panizzi et al., 2003) from cross [(BR79$15807 \times$ Embrapa 4) $\times$ IAC 13] has small seed size $(10 \mathrm{~g} / 100$ seeds), yellow hilum and high protein content $(43 \%)$, and it is suitable for natto and for production of soybean sprouts, as moyashi. BRS 213 (Carrão-Panizzi et al., 2002) was released for commercial production because it does not present the three lipoxygenases isoenzymes L1, L2 and L3 and probably presents better flavour. Genetic elimination of lipoxygenase enzymes can improve the flavour of soybean by reducing the formation of the hexanal compound associated with the beany flavour (Liu, 1999). BRS 267 shows large seed size and yellow hilum, which are suitable characteristics for 
soy food processing including tofu, soy flour and soymilk (Carrão-Panizzi et al., 2006). When harvested at the R6 stage (developed grains, but immature) (Fehr \& Caviness, 1977), this cultivar can also be consumed as green vegetable soybean, or edamame.

Silva et al. (2009) studied the chemical characteristics of these soybean cultivars and conclude that BRS 213 can improve the flavour of soy products owing to the absence of lipoxygenase enzymes and the lower hexanal content $\left(15.19 \mu \mathrm{mol} \mathrm{mg}^{-1}\right)$ when compared with conventional soybean cultivars BRS $133\left(17.45 \mu \mathrm{mol} \mathrm{mg} \mathrm{mg}^{-1}\right)$ and BRS $258\left(17.27 \mu \mathrm{mol} \mathrm{mg}^{-1}\right)$. BRS 267 is the best cultivar owing to the lower hexanal content $(7.46 \mu \mathrm{mol}$ $\mathrm{mg}^{-1}$ ), the higher content of protein, sucrose, and glutamic and alanine amino acids. BRS 216 is suitable for the production of natto and soybean sprouts owing to the small grain size. The sensory attributes of these Brazilian soybean cultivars have not been described previously in the literature.

The quality of food has been assessed using many different analytical tools to identify chemical, physical and sensory characteristics, including high-performance liquid chromatography (HPLC), gas chromatography and sensory analysis. Among the sensory methods, quantitative descriptive analysis (QDA) provides a complete description of the all sensory characteristics of products. However, all these methods are timeconsuming and expensive (Stone \& Sidel, 1993, 2004; Meilgaard et al., 2003). The use of electronic sensors or the electronic tongue for food assessment can provide rapid and precise results of taste and flavour and can also function as a tool to augment the work of sensory scientist. The electronic tongue is considered an important tool to optimise the quality control of beverage and foodstuffs in industries in order to discriminate and quantify the compounds of basic tastes in levels far below the detection limit or threshold of the human tongue, for example, $5 \mathrm{~mm}$ of $\mathrm{NaCl}$ or sucrose (Mattoso et al., 2002; Munõz, 2002; Costell, 2002; Desingh, Stone \& Thompson, 2004). The electronic tongue uses the human language concept, known as global selectivity, that is, the biological system does not identify a particular substance, but brings together all the information into patterns that the brain decodes. Electronic tongue needs well-established calibration standards, with samples throughout the range tested and a previous classification by another method (Riul et al., 2003). It does not premise the data, but compares the measurements with a database. QDA and the electronic tongue data have been evaluated using the multivariate statistical technique of principal component analysis (PCA) that elucidates the relationship between samples and the attributes that best characterise each sample (Stone \& Sidel, 2004; Ferreira, 2008). There are several works that use the electronic tongue to assess different beverage (Laureati et al., 2010; He et al., 2009; Bleibaum et al.,
2002; Kantor et al., 2008), but none about its application for assessing grains such as soybean. This work studies the sensory attributes of Brazilian soybean cultivars grain type (BRS 133 and BRS 258) and food type or for human consumption (BRS 213, BRS 216 and BRS 267) using the QDA and verifies the ability of electronic tongue to discriminate of soybean cultivars according to tastes and flavours.

\section{Materials and methods}

\section{Materials}

For this study, the following Brazilian soybean cultivars were genetically evaluated: conventional soybean cultivars (grain type) BRS 133 and BRS 258, and soybean cultivars for human consumption (food type) BRS 213 (null lipoxygenase), BRS 216 (small grain type) and BRS 267 (vegetable-type). The soybeans were supplied by Embrapa Soja, located in Londrina, Paraná, Brazil, and were produced in the 2005/2006 growing season in the region of Ponta Grossa, Paraná, Brazil (latitude: $25^{\circ} 09^{\prime}$; longitude: $50^{\circ} 16^{\prime}$; altitude: $975^{\circ} \mathrm{m}$; with average annual temperature of $17.6^{\circ} \mathrm{C}$ ).

\section{Sensory evaluation}

The quantitative descriptive analysis (QDA) was performed on the cooked soybeans and was conducted in agreement with the procedures proposed by Stone \& Sidel (2004). For the cooking process, the soybean grains were soaked in distilled water for $16 \mathrm{~h}$ at room temperature $\left(25^{\circ} \mathrm{C}\right)$. Next, the soybean grains were cooked in an autoclave (Fabre, model 103) at $121{ }^{\circ} \mathrm{C}$ for $5 \mathrm{~min}$ as mimic industrial preparation. In both descriptor development and evaluation sessions, the panelists were instructed to rinse their mouth with mineral water at room temperature $\left(25^{\circ} \mathrm{C}\right)$ before assessing a sample, and there was a $5 \mathrm{~min}$ break between the evaluations. Samples, coded with three-digit numbers during group and individual sessions, were presented in $50-\mathrm{mL}$ plastic cups with lids, with each cup containing ten grains of cooked soybeans and cooking broth for a better aroma perception. The samples were kept in a water bath during the evaluations and were served at a temperature of $45^{\circ} \mathrm{C}$. Ten panelists (four men, six women, ages ranging from 28 to 45) were selected from the Embrapa Soybean employees, and the sensory questionnaire, recognition test of basic taste and odours, ordering tests of hardness and colour intensity, astringency and bitterness intensity were used (Meilgaard et al., 2003). The grid method was used to develop the descriptive terminology (Moskowittz, 1983). The sensory attributes generated by consensus among the panelists were: appearance (grain size, cream colour of grain, grain shape, hilum colour), aroma (rancid, cooked beans and sweetness), flavour 
(rancid, cooked beans, sweet, bitter, astringent, umami) and texture (hardness) (Table 1). The panelists were trained to identify and quantify the attributes using references samples (Table 1). After training, the performance of each panelist was evaluated. For this, panelists evaluated three soybean cultivars, in three replication. The date of replications of the each panelist was analysed using a two-factor (samples and repetitions) ANOVA and $F$ test. To select panelists by discrimination ability, they had to present values of $F_{\text {samples }}$ with a level of significance below 50\% $(P<0.50)$. For repeatability, panelists with values of $F_{\text {repetitions }}$ with a level of significance above 5\% $(P>0.05)$ were selected. For evaluation of the agreement of the panelists with the panel, the average individual scores were compared to panel scores (Silva, Felberg, Carrão-Panizzi, Lee \& Prudencio, 2010; Damásio \& Costell, 1991; ABNT. NBR 14 140, 1998; Richter et al., 2010).

The trained panelists evaluated the five samples, in replication, in individual booths under fluorescent white light at room temperature $\left(25^{\circ} \mathrm{C}\right)$. The samples were presented randomly and sequentially tested by the panelists who evaluated the attributes using the scorecard that was developed during the training sessions. The scale used was a $9-\mathrm{cm}$ unstructured line with words anchored at 0.0 or $0.5 \mathrm{~cm}$ from the left end, indicating no or

Table 1 Definitions of sensory attributes for cooked soybean grains

\begin{tabular}{|c|c|c|}
\hline Sensory attribute & Definition & Reference \\
\hline \multicolumn{3}{|l|}{ Appearance } \\
\hline Grain size & Refers to the size of the grains. & $\begin{array}{l}\text { Small: raw grain of lentil. } \\
\text { Big: raw grain of white beans. }\end{array}$ \\
\hline Grain shape & $\begin{array}{l}\text { Refers to the appearance of grains } \\
\text { (elongated or round). }\end{array}$ & $\begin{array}{l}\text { Elongate: raw grain of white bean. } \\
\text { Round: canned green pea beans. }\end{array}$ \\
\hline Cream colour grain & $\begin{array}{l}\text { White-yellow intensity like the cream } \\
\text { colouring. }\end{array}$ & $\begin{array}{l}\text { Clear: baby corn, canned Green. } \\
\text { Stronger: chick peas, boiled in distilled water for } 50 \text { min. }\end{array}$ \\
\hline Hilum colour & $\begin{array}{l}\text { Colour intensity of surface area of grains } \\
\text { in which it holds the cord. }\end{array}$ & $\begin{array}{l}\text { Clear: soybean cultivar BRS } 213 \text { cooked in distilled water and } \\
\text { in an autoclave at } 121^{\circ} \mathrm{C} \text { for } 5 \mathrm{~min} \text {. } \\
\text { Dark: soybean cultivar BRS } 133 \text { cooked in distilled water and in } \\
\text { an autoclave at } 121^{\circ} \mathrm{C} \text { for } 5 \mathrm{~min} \text {. }\end{array}$ \\
\hline \multicolumn{3}{|l|}{ Aroma } \\
\hline Rancid & Aroma or smell of old frying oil. & $\begin{array}{l}\text { None: distilled water. } \\
\text { Strong: two drops of soy oil diluted in } 50 \mathrm{~mL} \text { of distilled water } \\
\text { and heated in microwave for } 10 \mathrm{~min} .\end{array}$ \\
\hline Cooked bean & Aroma or smell similar to cooked beans. & $\begin{array}{l}\text { None: distilled water. } \\
\text { Strong: beans cooked in distilled water in a pressure cooker for } \\
50 \mathrm{~min} \text {. }\end{array}$ \\
\hline Sweetness & Aroma associated with sweet foods. & $\begin{array}{l}\text { Weak: lentil beans cooked in distilled water for } 30 \text { min. } \\
\text { Strong: mini corn canned boiled in distilled water for } 50 \text { min. }\end{array}$ \\
\hline \multicolumn{3}{|l|}{ Flavour } \\
\hline Cooked bean & Flavour related with cooked beans. & $\begin{array}{l}\text { None: distilled water. } \\
\text { Strong: beans, boiled in distilled water, and pressure cooker for } \\
50 \mathrm{~min} \text {. }\end{array}$ \\
\hline Rancid & Flavour related with old frying oil. & $\begin{array}{l}\text { None: distilled water. } \\
\text { Strong: two drops of soy oil diluted in } 50 \mathrm{~mL} \text { of distilled water } \\
\text { and heated in microwave for } 10 \mathrm{~min} \text {. }\end{array}$ \\
\hline Sweet & Sweet taste. & $\begin{array}{l}\text { None: distilled water. } \\
\text { Strong: sucrose solution in distilled water at } 0.5 \% \text {. }\end{array}$ \\
\hline Bitter & Caffeine taste. & $\begin{array}{l}\text { None: distilled water. } \\
\text { Strong: caffeine solution in distilled water at } 0.02 \% \text {. }\end{array}$ \\
\hline Astringent & $\begin{array}{l}\text { Associated with the tannic acid solution } \\
\text { that causes the sensation of 'tying' the } \\
\text { mouth. }\end{array}$ & $\begin{array}{l}\text { None: distilled water. } \\
\text { Strong: tannic acid solution in distilled water at } 0.01 \% \text {. }\end{array}$ \\
\hline Umami & $\begin{array}{l}\text { Taste associated with monosodium } \\
\text { glutamate solution that remembers } \\
\text { of salty and sweet food at the same time. }\end{array}$ & $\begin{array}{l}\text { None: distilled water. } \\
\text { Strong: solution of monosodium glutamate in distilled water at } \\
0.08 \% \text {. }\end{array}$ \\
\hline \multicolumn{3}{|l|}{ Texture } \\
\hline Hardness & $\begin{array}{l}\text { Force required to compress the grain } \\
\text { between one's teeth. }\end{array}$ & $\begin{array}{l}\text { Low: beans cooked in distilled water in a pressure cooker for } \\
50 \mathrm{~min} \text {. } \\
\text { High: chickpeas cooked in distilled water for } 30 \mathrm{~min} \text {. }\end{array}$ \\
\hline
\end{tabular}


minimal intensity, respectively, and at $0.5 \mathrm{~cm}$ from the right end, indicating maximum intensity of the attributes (ABNT. NBR 14 140, 1998; Richter et al., 2010).

\section{Electronic tongue}

The cooked soybean grains were analysed in the laboratory of the Polytechnic School of Microelectronic, Universidade de São Paulo (USP), São Paulo, Brazil, with an electronic tongue composed of eight polymeric sensors with non-specific units, as defined in previous articles (Gregorut et al., 2009; Silva, 2009; Gregorut, 2010). For this analysis, the cooked soybean samples were crushed during their cooking preparation and then filtered through a cotton cloth by mechanical force application. Next, the filtered samples were diluted in distilled water at a ratio of 1:10 (v/v), homogenised and filtered using filter paper $(14 \mu \mathrm{m})$. The electronic sensors were fabricated by the self-assembly technique using an automatic film deposition (Braga et al., 2008; Gregorut et al., 2009). For the films, different conducting polymers acquired in the market were used. The electrical impedance measurements were obtained from an impedance type meter (LCR Meter HP 4263A model), interfaced with a computer through a GPIB card. The measurements were performed at a previously fixed frequency of $1 \mathrm{kHz}$ and an alternating voltage of $50 \mathrm{mV}$.

\section{Chemical constituents}

The hexanal and fatty acids contents were measured by gas chromatography analysis (GC); isoflavones, sugar and amino acids contents were analysed by HPLC. All these analyses were described in detail in the work published by Silva et al. (2009).

\section{Experimental design and statistical analysis}

QDA was conducted according to a two-factor (cultivars and panelists) design with three replications in different sessions. The data were analysed using PCA and twofactor analysis of variance (ANOVA) with the interaction (cultivars x panelists). The values of $F_{\text {cultivars x panelists }}$ were significant $(P \leq 0.05)$ for some attributes. Thus, the values of the adjusted $F_{\text {cultivars }}$ and the $t$-test (Fisher's Protected LSD) comparison of means were calculated against interaction mean square terms (cultivars $\times$ panelists) (O'Mahony, 1985; Stone \& Sidel, 2004). The analysis of the cooked soybean grains using the electronic tongue was conducted as an experimental randomized design with three replications and five measurements for each repetition. The results were subjected to PCA. The relationships between the sensory evaluation means, electronic tongue and chemical constituents of soybean flavour and taste were examined using Pearson's correlations coefficient $(r)(P \leq 0.05)$. PCA was based on the correlation matrix. The number of components used in the analysis met the minimum criterion of $80 \%$ of retention of original information data (Johnson \& Wichern, 1998). The statistical tests were performed using SAS Institute (2001)- and STATISTICA program, version 6.0 (StatSoft, Tulsa, OK, USA).

\section{Results and discussion}

\section{Sensory evaluation}

Figure 1a shows the projection of sensory attributes on the factorial plane $(\mathrm{PC} 1 \times \mathrm{PC} 2)$ of $\mathrm{PCA}$, and Fig. $1 \mathrm{~b}$ shows the projection of conventional soybean cultivars BRS 133 and BRS 258, and soybean cultivars for human (a)

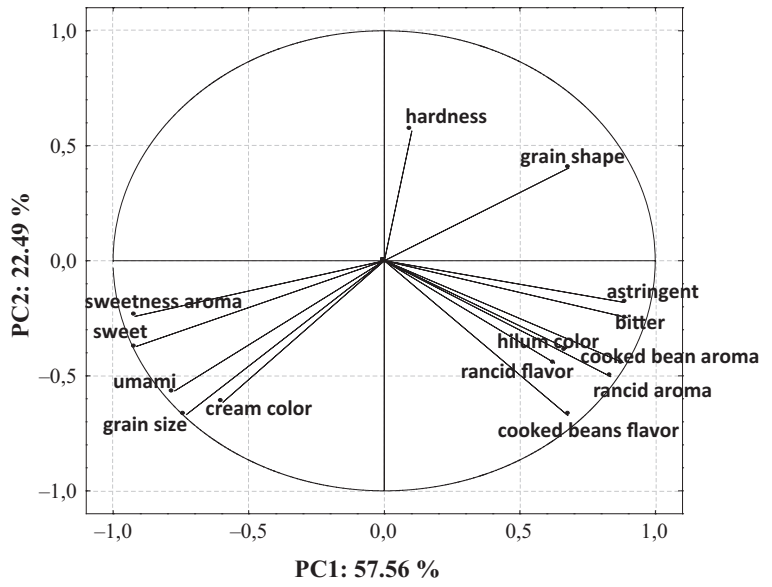

(b)

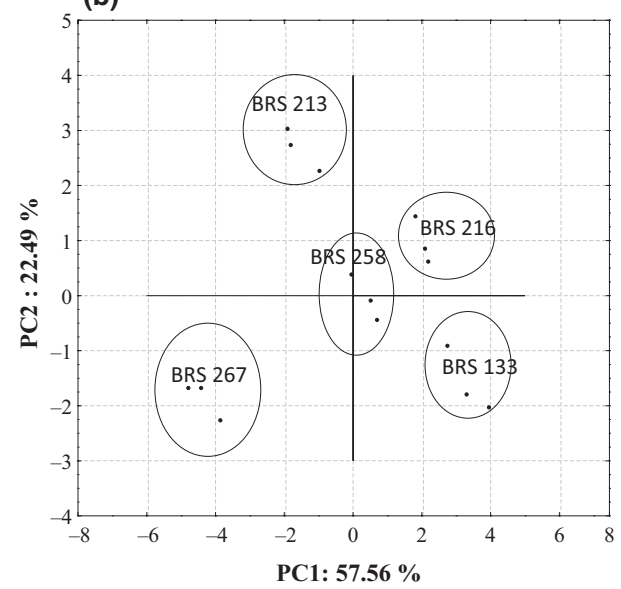

Figure 1 Projections of the sensory attributes (a) and soybean cultivars (b) on the factorial plane (PC1 and PC2). b: Brazilian soybean cultivar BRS 213; Brazilian soybean cultivar BRS 216; Brazilian soybean cultivar BRS 267; Brazilian soybean cultivar BRS 258; Brazilian soybean cultivar BRS 133. 
consumption BRS 213 (null lipoxygenase), BRS 216 (small grain size) and BRS 267 (vegetable-type). The first principal component (PC1) explained $57.56 \%$ of the total variability contained in the original variables, and the second principal component (PC2) accounted for a further $22.49 \%$, for a cumulative percentage of $80.05 \%$. The variability explained in the first PC included attributes that had loadings above 0.7 (in absolute value) and in descending order of importance (discriminative contribution) with a positive correlation with bitter taste, astringency, rancid flavour and rancid aroma, and a negative correlation with sweetness aroma, sweet taste, umami and cream grain colour. Thus, PC1 represents the attributes of flavour of soybeans. The attributes that contributed to the second PC, with a positive correlation $(>0.5)$, were grain size and hardness. The repetitions of analysis of each cultivar (represent by points) are close; it means that there was a good repeatability. The five soybean cultivars are separated from one another by presenting different sensory attributes. The first PC separated the cultivars BRS 213 and BRS 267 (far left, Fig. 1b) from the BRS 216 and BRS 133 (far right, Fig. 1b). As soybean cultivars located more to the left probably had a higher intensity of sensory attributes, located more to the left in Fig. 1a, and the lower intensity of the attributes are located further to the right. As the soybean cultivars located more to the right exhibit a possible greater intensity of the attributes located more to the right of Fig. 1a and lower intensity of the attributes located to the left, the PC2 separated the cultivars BRS 213 and BRS 216 (above) from the BRS 267 and BRS 133 (below). The cultivars located above probably have greater intensity of the attribute hardness. The BRS 258 located more to middle of the factorial plane can be considered a cultivar with intermediate-strength sensory characteristics.
The sensory analysis results of each attribute of the soybean cultivars were also subjected to analysis of variance (ANOVA) and average intensities (Table 2) in order to have the level of significance and to confirm the indications of the results of PCA about the attributes that best characterised each cultivar and to examine the similarities and differences between them. Therefore, based on PCA, ANOVA and $t$-test results, it can be observed that the food-type soybean cultivar BRS 267 (vegetable-type) was elicited by higher grain size, more intense cream colour, sweetness aroma, sweet and umami taste; BRS 216 was classified by the following attributes: smaller grain size, less intense cream colour and more rounded grain shape; and BRS 213 (null lipoxygenase) was characterised, in general, as a neutral flavour as it showed, similar to the cultivar BRS 267, the lowest intensity of the rancid and cooked bean aroma, rancid, bitter, astringent and cooked bean flavour. Soybean cultivar BRS 133 exhibited a darker hilum colour, rancid and cooked bean aroma, rancid, bitter and astringent cooked bean flavour, while the BRS 258 showed a hard texture. The difference in food-type (BRS 213 and BRS 267) and grain-type (BRS 133) soybean cultivars can be associated with higher sugar contents and amino acid, glutamic acid and alanine (Silva et al., 2009), which consequently are responsible for the greater intensity perception in the sweet and umami taste found in the vegetable-type soybean cultivar. Probably, sugars and amino acids were precursors of volatiles compounds that were formed during cooked processing of grains and contribute with sweetness aroma.

\section{Electronic tongue measurements}

The projection of soybean cultivars on the factorial plane (PC1 and $\mathrm{PC} 2$ ) is shown in Fig. 2a, and the projection of the eight electronic sensors in Fig. 2b. The

Table 2 Average intensities of sensory attributes related to appearance, aroma, flavour and texture of soybean cultivars*

\begin{tabular}{|c|c|c|c|c|c|c|c|}
\hline Cultivars & Grain size & Appearance grain shape & Cream colour & Hilum colour & Rancid & Aroma cooked bean & Sweet \\
\hline BRS 213 & $2.80^{d}$ & $5.00^{\mathrm{b}}$ & $2.21^{\mathrm{cd}}$ & $0.58^{d}$ & $0.61^{\mathrm{c}}$ & $1.27^{\mathrm{c}}$ & $1.89^{\mathrm{b}}$ \\
\hline BRS 216 & $1.89^{\mathrm{e}}$ & $6.00^{\mathrm{a}}$ & $1.78^{d}$ & $1.30^{\mathrm{c}}$ & $2.16^{\mathrm{b}}$ & $1.68^{\mathrm{ab}}$ & $1.10^{\mathrm{c}}$ \\
\hline BRS 267 & $8.36^{\mathrm{a}}$ & $1.24^{\mathrm{C}}$ & $6.48^{\mathrm{a}}$ & $0.88^{\mathrm{cd}}$ & $1.05^{\mathrm{c}}$ & $1.36^{\mathrm{bc}}$ & $3.58^{\mathrm{a}}$ \\
\hline BRS 258 & $7.22^{\mathrm{b}}$ & $1.58^{\mathrm{c}}$ & $3.57^{b}$ & $7.15^{b}$ & $1.94^{\mathrm{b}}$ & $1.37^{\mathrm{bc}}$ & $1.03^{\mathrm{c}}$ \\
\hline BRS 133 & $3.81^{\mathrm{c}}$ & $5.73^{\mathrm{ab}}$ & $2.76^{\mathrm{c}}$ & $8.41^{\mathrm{a}}$ & $3.85^{\mathrm{a}}$ & $1.75^{\mathrm{a}}$ & $0.75^{\mathrm{c}}$ \\
\hline Cultivars & Cooked bean & Rancid & Flavour sweet & Bitter & Astringent & Umami & Texture hardness \\
\hline BRS 213 & $1.45^{\mathrm{b}}$ & $0.68^{\mathrm{c}}$ & $1.48^{\mathrm{b}}$ & $0.95^{\mathrm{b}}$ & $1.00^{\mathrm{b}}$ & $0.06^{b}$ & $4.47^{b}$ \\
\hline BRS 216 & $1.78^{\mathrm{a} b}$ & $2.21^{\mathrm{b}}$ & $0.80^{\mathrm{c}}$ & $2.06^{\mathrm{a}}$ & $1.97^{\mathrm{a}}$ & $0.04^{\mathrm{b}}$ & $3.87^{\mathrm{b}}$ \\
\hline BRS 267 & $1.69^{b}$ & $0.96^{\mathrm{c}}$ & $3.26^{\mathrm{a}}$ & $1.03^{b}$ & $1.00^{\mathrm{b}}$ & $2.75^{a}$ & $2.82^{\mathrm{C}}$ \\
\hline BRS 258 & $1.80^{\mathrm{a} b}$ & $1.86^{\mathrm{b}}$ & $1.14^{\mathrm{bc}}$ & $1.81^{\mathrm{a}}$ & $1.67^{\mathrm{a}}$ & $0.05^{\mathrm{b}}$ & $5.52^{\mathrm{a}}$ \\
\hline BRS 133 & $2.23^{\mathrm{a}}$ & $3.40^{\mathrm{a}}$ & $0.83^{c}$ & $2.04^{\mathrm{a}}$ & $1.84^{\mathrm{a}}$ & $0.03^{b}$ & $2.98^{\mathrm{c}}$ \\
\hline
\end{tabular}

* Mean values of three replicates and ten panelists for each repetition, obtained from a nine-point scale $(0=$ none and $9=$ superior $)$; means in columns followed by the same letter do not differ at $5 \%$ probability by $t$-test. 
(a)

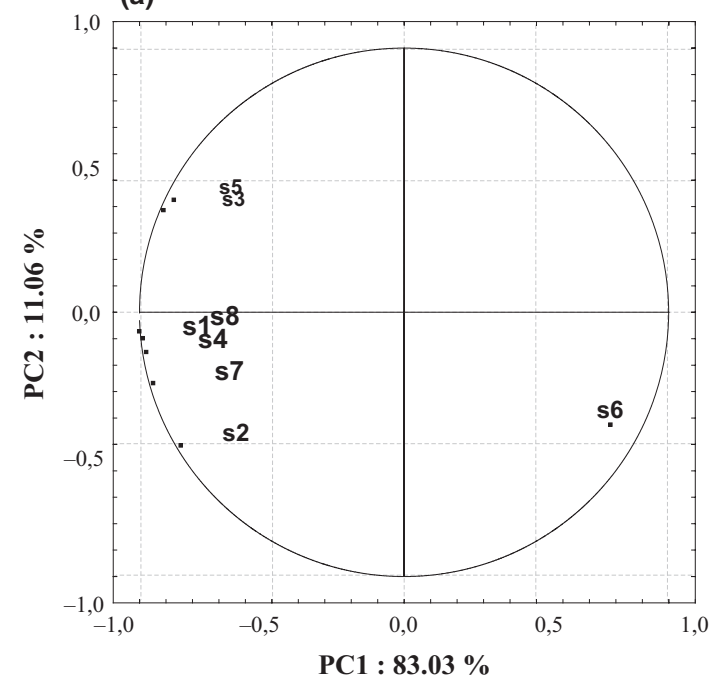

(b)

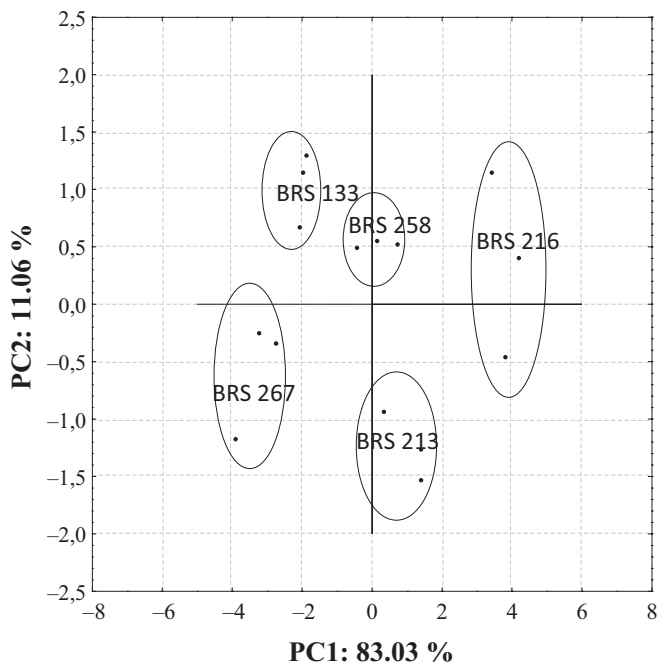

Figure 2 Projection of electronic sensors (a) on the factorial plane (PC1 and PC2) in the frequency of $1 \mathrm{kHz}$, and projection of soybean cultivars (b) in three replicates. a: $\mathrm{S} 1=$ sensor $1 ; \mathrm{S} 2=$ sensor 2; $\mathrm{S} 3=$ sensor 3; $\mathrm{S} 4=$ sensor 4; $\mathrm{S} 5=$ sensor 5; $\mathrm{S} 6=$ sensor 6; $\mathrm{S} 7=$ sensor 7; $\mathrm{S} 8=$ sensor 8. b: Brazilian soybean cultivar BRS 213; Brazilian soybean cultivar BRS 216; Brazilian soybean cultivar BRS 267; Brazilian soybean cultivar BRS 258; Brazilian soybean cultivar BRS 133.

first principal component (PC1) explained $83.0 \%$ of the total variation among the data, whereas the second principal component (PC2) accounted for a further $11.1 \%$, for a cumulative percentage of $94.1 \%$. The proximate of replicate of analysis of each cultivar (represented by points) indicates a good repeatability. It can be verified by the PCA that the electronic tongue, composed of eight sensors, was sufficient to identify and classify the cultivars into five different cultivars. The variability among the data $(83 \%)$ explained in the first PC (Fig. 2b) was probably due to sensors 1, 4, 7 and 8 (loadings above 0.7 , in absolute value). In the second PC, $11.06 \%$ of the variability in the data was attributed to the sensors 2, 3, 5 and 6. Comparing the PCA graphs with the data obtained through the QDA (Fig. 1) with the electronic tongue (Fig. 2), it can observed that electronic sensors, at a frequency of $1 \mathrm{kHz}$, result in responses similar to those by the trained panelists, that is, the soybean cultivars were sufficiently discriminated. Soybean cultivars BRS 213 and BRS 133 are positioned at an angle of 180 degrees, just like BRS 267 and BRS 216. This positioning indicates that in each of these pairs of cultivars, the attributes are at greater intensity in one cultivar and lower in another cultivar, and vice versa. As the BRS 267 and BRS 216 positioned between them at an angle of 180 degrees, BRS 133 and BRS 213 also positioned at an angle of between 180 degrees and BRS 258 in a more central position. These positions were attributed to the sensory characteristics in the soybean cultivars and were evaluated in a similar manner by the trained panelists or electronic sensors. Some studies found in the literature show the capability of the electronic tongue to discriminate different types of beverages and foods. However, others studies demonstrate the need to improve the methodology using electronic sensors according to the food or beverage evaluated. Legin et al. (2002), assessing the ability of the electronic tongue to distinguish commercial carbonated drinks containing different sweeteners, found that the equipment distinguished all samples and separated them from conventional drinks. The electronic sensors also discriminated drinks at the production locality, and the authors observed a good correlation with the results obtained in the QDA. Dyminski et al. (2006) noted that the electronic tongue was able to differentiate between sweetener samples at a high correlation with human panel response. He et al. (2009) found that the electronic sensors used in the evaluation of tea (black and green) were able to identify and discriminate drinks from between geographical regions and quality levels and correlated highly with the sensory measurements collected from trained assessors. Bleibaum et al. (2002) demonstrated that the electronic sensors can be used to predict the sensory characteristics and their relationship to the quality of apple juices measured by trained assessors and naive consumers.

\section{Correlation of sensory analysis, electronic tongue and chemical constituents}

Table 3 shows the correlation analysis results between sensory attributes and chemical constituents of soybean 
Sensory studies of different soybean cultivars J. Da Silva et al.

Table 3 Pearson's correlations coefficient $(r)$ between sensory attributes and chemical constituents of soybean cultivars*

\begin{tabular}{|c|c|c|c|c|c|}
\hline Sensory attributes & Hexanal & Isoflavones & $\begin{array}{l}\text { Linoleic and } \\
\text { linolenic acids }\end{array}$ & $\begin{array}{l}\text { Sucrose and } \\
\text { fructose }\end{array}$ & $\begin{array}{l}\text { Glutamic acid } \\
\text { and alanine }\end{array}$ \\
\hline Grain size & -0.37 & -0.09 & $0.76^{*}$ & 0.07 & $0.84 *$ \\
\hline Cream colour & $-0.68^{*}$ & 0.28 & $-0.89 *$ & 0.45 & $0.91 *$ \\
\hline Texture & $-0.90^{*}$ & 0.44 & $-0.81 *$ & $0.59 *$ & 0.32 \\
\hline Rancid aroma & $0.51 *$ & 0.22 & $0.66^{*}$ & 0.11 & 0.11 \\
\hline Cooked beans aroma & 0.24 & 0.36 & $0.71^{*}$ & 0.36 & -0.07 \\
\hline Sweetness aroma & $-0.88^{*}$ & 0.39 & $-0.95^{*}$ & $0.55^{*}$ & $0.57^{*}$ \\
\hline Cooked beans flavour & $0.52^{*}$ & 0.17 & $0.72 *$ & 0.08 & 0.03 \\
\hline Rancid flavour & $0.69^{*}$ & 0.30 & 0.48 & 0.21 & 0.33 \\
\hline Sweet & $-0.83^{*}$ & 0.37 & $-0.98^{*}$ & $0.52 *$ & $0.71 *$ \\
\hline Bitter & $0.55^{*}$ & -0.03 & $0.81 *$ & -0.05 & -0.11 \\
\hline Astringent & 0.49 & -0.21 & $0.85^{*}$ & -0.13 & -0.29 \\
\hline Umami & $-0.88^{*}$ & 0.47 & $-0.89 *$ & $0.68^{*}$ & $0.79 *$ \\
\hline
\end{tabular}

*Significant correlation test, $P \leq 0.05$

Table 4 Pearson's correlations coefficient $(r)$ between chemical constituents of soybean cultivars and electronic sensor at $1 \mathrm{kHz}$ frequency*

\begin{tabular}{lllll}
\hline Electronic & $\begin{array}{l}\text { Linoleic and } \\
\text { linolenic } \\
\text { sensor }\end{array}$ & lsoflavones & $\begin{array}{l}\text { Sucrose } \\
\text { and } \\
\text { fructose }\end{array}$ & $\begin{array}{l}\text { Glutamic } \\
\text { acid and } \\
\text { alanine }\end{array}$ \\
\hline Sensor 1 & $0.61^{*}$ & 0.34 & 0.08 & $0.64^{*}$ \\
Sensor 2 & 0.36 & $0.71^{*}$ & 0.22 & $0.67^{*}$ \\
Sensor 3 & $0.52^{*}$ & 0.27 & -0.07 & $0.61^{*}$ \\
Sensor 4 & 0.45 & 0.20 & -0.07 & $0.55^{*}$ \\
Sensor 5 & 0.49 & 0.45 & 0.06 & $0.63^{*}$ \\
Sensor 6 & -0.46 & $-0.94^{*}$ & $-0.59^{*}$ & -0.44 \\
Sensor 7 & 0.39 & 0.14 & -0.13 & $0.73^{*}$ \\
Sensor 8 & $0.58^{*}$ & $0.50^{*}$ & 0.24 & $0.68^{*}$ \\
\hline
\end{tabular}

*Significant correlation test, $P \leq 0.05$

cultivars. These results of the constituent contents are shown in Silva et al. (2009). Hexanal and fatty acids contents presented positive and significant correlations with rancid and cooked beans aroma, rancid, bitter, astringent and cooked beans flavour, and significant and negative correlations with a sweet aroma, sweetness and umami. These results confirmed those obtained by Torres-Penaranda \& Reitmeier (2001). Isoflavone contents did not show significant correlations with the sensory attributes of bitter and astringent, different from those obtained by other authors (Huang et al., 1981; Kudou et al., 1991). It may be that the time and temperature to which the soybeans were subjected to during the cooking process were not sufficient for the formation of aglycones from the isoflavone in sufficient quantities for the sensory perception of the aforementioned sensations. Sugars and amino acids show positive and significant correlations with sweetness aroma, sweet and umami taste. Masuda (1991) showed correlations among sucrose, glutamic acid and alanine with the sweet
Table 5 Pearson's correlations coefficient $(r)$ between sensory attributes of soybean cultivars and electronic sensors at $1 \mathrm{kHz}$ frequency*

\begin{tabular}{lcccccc}
\hline $\begin{array}{l}\text { Sensory } \\
\text { attributes/ } \\
\text { electronic } \\
\text { sensor }\end{array}$ & $\begin{array}{l}\text { Cooked } \\
\text { beans } \\
\text { flavour }\end{array}$ & $\begin{array}{l}\text { Rancid } \\
\text { flavour }\end{array}$ & $\begin{array}{l}\text { Sweet } \\
\text { taste }\end{array}$ & $\begin{array}{l}\text { Bitter } \\
\text { taste }\end{array}$ & Astringent & Umami \\
\hline Sensor 1 & 0.21 & -0.10 & $0.72^{*}$ & -0.42 & $-0.50^{*}$ & $0.73^{*}$ \\
Sensor 2 & -0.19 & -0.45 & $0.76^{*}$ & $-0.74^{*}$ & $-0.80^{*}$ & $0.66^{*}$ \\
Sensor 3 & $0.60^{*}$ & $0.65^{*}$ & 0.33 & 0.04 & -0.06 & 0.41 \\
Sensor 4 & 0.16 & -0.13 & $0.65^{*}$ & -0.45 & $-0.54^{*}$ & $0.63^{*}$ \\
Sensor 5 & $0.65^{*}$ & $0.62^{*}$ & 0.26 & 0.09 & 0.00 & 0.35 \\
Sensor 6 & -0.48 & -0.25 & -0.36 & 0.00 & 0.08 & -0.43 \\
Sensor 7 & 0.04 & -0.25 & $0.79^{*}$ & $-0.58^{*}$ & $-0.66^{*}$ & $0.76^{*}$ \\
Sensor 8 & 0.25 & -0.05 & $0.69^{*}$ & -0.39 & -0.47 & $0.71^{*}$ \\
\hline
\end{tabular}

*Significant correlation test, $P \leq 0.05$

and umami taste that describes the unique flavour of vegetable-type soybean. Table 4 shows the correlations between the chemical constituents of soybean cultivars and electronic sensors at the frequency of $1 \mathrm{kHz}$. Positive and significant correlations with linoleic and linolenic fatty acids were found for sensors 1,3 and 8 . The isoflavone contents showed significant positive correlations with sensors 2 and 8. Glutamic acid and alanine had positive and significant correlations with the sensors 1, 2, 3, 4, 5, 7 and 8. Among the sensors used, sensor 6 showed $r=-0.58$ and $P \leq 0.05$ with sucrose and fructose. Table 5 shows the correlations between the sensory attributes and electronic sensors. Cooked beans and rancid flavours showed positive and significant correlations $(P \leq 0.05)$ with sensors 3 and 5. Sweet and umami taste showed positive and significant correlations with sensors $1,2,4,7$ and 8 . The results suggest that sensors 3 and 5 may be more correlated with the sensory attributes of cooked beans and rancid flavours, and sensors 1, 2, 4, 7 and 8 with the sweet and umami tastes. 
Five sensors showed noncorrelation with astringency, and sensor 6 with the bitter taste.

The electronic tongue is an artificial system that tries to reproduce the sensory analysis mechanism of taste and flavour of products and can be a tool to augment the work of sensory scientist (Riul et al., 2002; Ciosek \& Wroblewski, 2007). The equipment needs well-established calibration standards, with samples throughout the range tested and a previous classification by another method. It does not premise the data, but compares the measurements with a database. When the correlation between the instrumental and sensory results is significant, the electronic tongue can replace the sensory analysis, only for taste and flavour, by providing a rapid and qualitative analysis. In this study, we showed the possibility of the electronic tongue to assess the taste and flavour of solid foods from aqueous extracts of soybean grains.

\section{Conclusion}

Soybean cultivars studied have different sensory attributes. Food-type BRS 267 has higher grain size, intense cream colour, sweetness aroma, sweet and umami taste; BRS 216 has smaller grain size, less intense cream colour and more rounded grain shape; and BRS 213 has a neutral flavour. Grain-type BRS 133 has a darker hilum colour, rancid and cooked bean aroma, rancid, bitter and astringent cooked bean flavour, while the BRS 258 has a hard texture. Sensory attributes has a good correlation with the chemical constituents of soybean grains. Electronic tongue has a good correlation with the chemical constituents and with flavour attributes of soybean grains. The electronic tongue differentiates the soybean grains similar to the trained panel, and it can be an analytical tool to discriminate soybean cultivars according to flavour, quickly and efficiently.

\section{Acknowledgments}

The financial support given by MCT/FINEP, CNPq, CAPES, Fapesp, USP, UEL and Embrapa is gratefully acknowledged.

\section{References}

ABNT. NBR 14 140. (1998). Alimentos e Bebidas - Análise sensorial Teste de análise descritiva quantitative (ADQ). 5.

Benassi, M.T., Richter, V.B., Almeida, T.C.A. \& Prudencio, S.H. (2010). Proposing a ranking descriptive sensory method. Food Quality and Preference, 21, 611-620.

Bleibaum, R.N., Stone, H., Tan, T., Labreche, S., Saint-Martin, E. \& Isz, S. (2002). Comparison of sensory and consumer tongue results with electronic nose and tongue sensors for apple juices. Food Quality and Preference, 13, 409-422.

Braga, G.S., Paterno, L.G., Lima, J.P.H., Fonseca, F.J. \& Andrade, A.M. (2008). Influence of the deposition parameters on the morphology and electrical conductivity of PANI/PSS self-assembled films. Materials Science and Engineering $C, \mathbf{2 8}, 555-562$.
Carrão-Panizzi, M.C, Almeida, L.A, Miranda, L.C et al. (2002). BRS 213: Nova cultivar de soja para alimentação humana. In: Congresso Brasileiro de Soja, Mercosoja 2002, Foz do Iguacu, PR. Resumos (edited by Saraiva O. F. \& Hoffman-Campo C. B.). Pp. 201. Londrina: Embrapa Soja. (Embrapa Soja. Documentos 181).

Carrão-Panizzi, M.C, Almeida, L.A, Kiihl, R.A.S et al. (2003). Indicação da cultivar de soja BRS 216 para o estado de São Paulo. In: Reunião de Pesquisa de Soja da Região Central do Brasil, 25, 2003, Uberaba. Resumos (edited by Saraiva O. F. \& Campos Leite R. M. V. B). Pp. 51-52. Londrina: Embrapa Soja: EPAMIG: Fundação Triângulo. (Embrapa Soja. Documentos 209).

Carrão-Panizzi, M.C., Pípolo, A.E., Almeida, L.A. et al. (2006). BRS 267: cultivar de soja para alimentação humana. In: Reunião de Pesquisa de Soja da Região Central do Brasil, 28, 2006, Uberaba. Resumos (edited by Saraiva O. F., Campos Leite R. M. V. B. \& Ortiz J. L.). Pp. 315-317. Londrina: Embrapa Soja: Fundação Meridional: Fundação Triângulo, 2006. (Embrapa Soja. Documentos, 272).

Ciosek, P. \& Wroblewski, W. (2007). Sensor arrays for liquid sensing electronic tongue systems. The Analyst, 132, 963-978.

Costell, E. (2002). A comparison of sensory methods in quality control. Food Quality and Preference, Issue, 35, 341-353.

Da Silva, J.B. (2009). Conventional soybean cultivars and for human consumption characteristics: physical, chemical and sensory analysis (human sense and electronic tongue). Thesis of doctor in Food Science. Londrina, Parana, Brazil: Universidade Estadual de Londrina. Available at: http://capesdw.capes.gov.br/capesdw/resumo.html?idtese $=20092240002012003$ P9

Damásio, M.H. \& Costell, E. (1991). Análisis sensorial descriptivo: generación de descriptores, y seleción de catadores. Revista Agroquímica y Tecnologia de Alimentos, 31, 165-178.

Deisingh, A.K., Stone, D.C. \& Thompson, M. (2004). Applications of electronic noses and tongues in food analysis. International Journal of Food Science \& Technology, 39, 587-604.

Dyminski, S.D., Paterno, L.G., Takeda, H.H., Bolini, H.M., Mattoso, L.H.C. \& Candido, L.M.B. (2006). Correlation between human panel and electronic tongue responses on the analysis of commercial sweeteners. Sensor Letters, 4, 1-6.

Fehr, W.R. \& Caviness, C.E. (1977). Stages of soybean development. Ames: Iowa State University of Science and Technology, 12p. (Special Report, 80).

Ferreira, F.D. (2008). Estatistica Multivariada, 1st edn. Lavras: UFLA, Pp. 662.

Gregorut, C. (2010). Performance evaluation of an electronic tongue in identification of soybeans. Master of Electrical Engineering, Polytechnic School. Available at http://www.teses.usp.br/teses/disponiveis/3/3140/tde-10012011-091647/pt-br.php.

Gregorut, C., Silva, J.B., Wiziack, N.K.L., Paterno, L.G., CarrãoPanizzi, M.C. \& Fonseca, F.J. (2009). Application of Electronic Tongue in Identification of Soybeans. In: International Symposium on Olfaction and Electronic Nose, 2009, Brescia. Proceedings of the 13th International Symposium. p. 533-534.

He, W., Hu, X., Zhao, L. et al. (2009). Evaluation of Chinese tea by the electronic tongue: correlation with sensory properties and classification according to geographical origin and grade level. Food Research International, 42, 1462-1467.

Huang, A., Hsieh, O.A.L. \& Chang, S.S. (1981). Characterization of the on volatile minor constituents responsible for the objectionable taste of defatted soybean flour. Journal Food Science, 47, 19-23.

Johnson, R.A. \& Wichern, D.W. (1998). Applied Multivariate Statistical Analysis, 4th edn. New Jersey: Prentice Hall, Pp. 816.

Kantor, D.B., Hitka, G., Fekete, A. \& Balla, C.S. (2008). Electronic tongue for sensing taste changes with apricots during storage. Sensors and Actuators B, 131, 43-47.

Kudou, S., Fleury, Y., Welti, D. et al. (1991). Malonil isoflavone glycosides in soybeans seeds (Glycine $\max ($ L.) Merrill). Agricultural and Biological Chemistry, 55, 2227-2233.

Laureati, M., Buratti, S., Bassoli, A., Borgonovo, G. \& Pagliarini, E. (2010). Discrimination and characterisation of three cultivars of 
Perilla frutescens by means of sensory descriptors and electronic nose and tongue analysis. Food Research International, 43, 959-964.

Legin, A., Rudnitskaya, A., Seleznev, B. \& Vlasov, Y. (2002). Recognition of liquid and flesh food using an electronic tongue. International Journal of Food Science and Technology, 37, 375-385.

Liu, K. (1999). Soybeans Chemistry Technology and Utilization. New York: Chapman and Hall, Pp. 532.

Masuda, R. (1991). Quality Requirement and Improvement of Vegetable Soybean. Vegetable Soybean Research Needs for Production and Quality Improvement, 92-102.

Mattoso, L.H.C., Taylor, D.M., Bone, S., Mello, S.V., Soto Gallardo, A.M. \& Riul, A. Jr (2002). An electronic tongue using polypyrrole and polyaniline. Synthetic Metals, 132, 109-116.

Meilgaard, M., Civille, G.V. \& Carr, B.T. (2003). Sensory Evolution Techniques. London: CRC Press. Inc., Pp. 387.

Moskowittz, H.R. (1983). Product. Testing and Sensory Evaluation of Foods. Marketing and $R \& D$. Approaches. London: Westport Food and Nutrition Press. Inc., pp. 605.

Munõz, A. (2002). Sensory evaluation in quality control in overview, new developments and future opportunities. Food Quality and Preference, 13, 329-339.

O'Mahony, M. (1985). Sensory Evaluation of Food: Statistical Methods and Procedures. New York, USA: Marcel Dekker Inc.

Pípolo, A.E, Almeida, L.A., Kiihl, R.A.S. et al. (2005). BRS 258 nova cultivar para alimentação humana. In: Reunião de Pesquisa de Soja da Região Central do Brasil, 27, 2005. Cornélio Procópio. Resumos (edited by Saraiva O. F.; Grosskopf S. E. In: Reunião de Pesquisa de Soja da Região). Pp. 371. Londrina: Embrapa Soja. (Embrapa Soja. Documentos, 257).
Richter, V.B., Almeida, T.C.A., Prudencio, S.H. \& Benassi, M.T. (2010). Proposing a ranking descriptive sensory method. Food Quality and Preference, 21, 611-620.

Riul, A. Jr, dos Santos, D.S., Wohnrath, K et al. (2002). Artificial taste sensor: efficient combination of sensors made from LangmuirBlodgett films of conducting polymers and a ruthenium complex and self-assembled films of an azobenzene-containing polymer. Langmuir, 18, 239-245.

Riul, A. Jr, Malmegrim, R.R., Fonseca, F.J. \& Mattoso, L.H.C. (2003). An artificial taste sensor based on conducting polymers. Biosensors and Bioelectronics, 18, 1365-1369.

SAS Institute. (2001). SAS user's guide: Statistics: Ver. 8.2, 6th edn. USA: Cary.

Silva, J.B. (2009). Conventional soybean cultivars and for human consumption characteristics: physical, chemical and sensory analysis (human sense and electronic tongue Universidade Estadual de Londrina. Tese (Doutorado em Ciência de Alimentos).

Silva, J.B., Carrão-Panizzi, M.C. \& Prudêncio, S.H. (2009). Chemical and physical composition of grain-type and food-type soybean for food processing. Brazilian Journal of Agricultural Research Brasilia, 44, 777-784.

Silva, J.B., Felberg, I., Carrão-Panizzi, M.C., Lee, S.I. \& Prudencio, S.H. (2010). Relationships among sensory analysis, isoflavone and hexanal contents of soymilk powder. Brazilian Archives of Biology and Technology, 53, 1197-1204.

Stone, H. \& Sidel, J.L. (1993). The role of sensory analysis in the food industry. Food Quality and Preference, 4, 65-75.

Stone, H. \& Sidel, J.L. (2004). Sensory Evaluation Practices. Food Science and Technology, 3rd edn. London: International Series Elsevier Academic Press, Pp. 377.

Torres-Penarnda, A.V. \& Reitmeier, C.A. (2001). Sensory Descriptive Analysis of Soymilk. Journal Food Science, 66, 352-356. 